\title{
Applying the Papakonstantinidis 3-ple-win-model on the Social Welfare System of the Labor Markets in Greece and Germany
}

\author{
Thomas Kronberger ${ }^{1}$, Leonidas Papakonstantinidis ${ }^{2,3,4, *}$ \\ ${ }^{1}$ Faculty of Management, Comenius University, Slovakia \\ ${ }^{2}$ School of Management and Economics, Technological Educational Institute, University of Peloponnesus, Greece \\ ${ }^{3}$ Institute of Information Technology (IIIT), Indian \\ ${ }^{4}$ Lampung University, Indonesia
}

Copyright $\bigcirc 2019$ by authors, all rights reserved. Authors agree that this article remains permanently open access under the terms of the Creative Commons Attribution License 4.0 International License

\begin{abstract}
The aim of this paper is to show the bargaining possibilities when there are three involved parties on a labor market and two of them are active decision-makers. The continuous conflict is between the three main bargaining power poles i.e., State; Company; Citizen. This conflict landscape is directly correlated with the development dynamical trends coming especially from the rapid rate of world urbanization: Market forces based on Instant Reflection Individual Mixed Strategies (IRIMS) between the three power poles i.e. Business, Citizen and the Community (State) shape the labor market by a continuous dynamic evolution. We will show possible solutions for increasing the benefit for all three parties. The "win-win-win papakonstantinidis model" with a 3-ple view in the labor market as the result of a continuous conflict among interests' power poles' i.e. Business-Citizen and the Community (State) for the domination over the labor market The 3ple win involvement, able to create equilibrium point in a pay-off matrix coming from "best responses", of the three stakeholders As introduction basic statistical data from Greece and Germany will be presented and structured. After this the different behaviors of the parties in both countries will be regarded and their bargaining success will be illustrated.
\end{abstract}

Keywords Social Welfare Systems, Labor Market, Bargaining Problem Decision Making, Stakeholders, Win-win-win, Profit Maximization

\section{Introduction}

During the 20th and early 21st centuries, the labor market underwent and still undergoes a lasting transformation from rural to industrial [1] [2], from industrial to the information age [3], and from information age to digitalization and automatisation.

According to another study [4] organization, governments and society are increasingly confronted with considerations that are less related with business and more about work, people and society as such. The future of jobs: a digitization challenge for all whether we like it or not: the road of ongoing automation can't be traveled with a purely micro-economic perspective alone. This change is likely to continue in the next decades of the 21st century, directly combined with the "labor market". Main Questions:

The continuous conflict between the three main bargaining power poles i.e.

$\begin{array}{ll}\text { - } & \text { State } \\ \text { - } & \text { Company } \\ & \end{array}$

At the local-state level Citizens, (and their interests lobbies), State and the Company, shapes the landscape of its management and operation. This conflict landscape is directly correlated with the development dynamical trends coming especially from the rapid rate of world urbanization: Market forces based on Instant Reflection Individual Mixed Strategies (IRIMS) between the three power poles i.e. Business, Citizen and the Community (State) shape the labor market by a continuous dynamic evolution. This evolution positively influences the labor market towards its spatial integration:

a. May the labor market be viewed as the result of a continuous conflict among interests' power poles' i.e. Business-Citizen and the Community (State) for the domination over the labor market?

b. Is the 3ple win involvement, able to create equilibrium point in a pay-off matrix coming from "best responses", of the three stakeholders? How the 3-ple win equilibrium is different (if it is) from that of the 2-poles game? 
c. Is there any possibility, the 3-win system to produce conflict Equilibria in a globalized and competitive world? What is the possibility ensuring the max profit for each of them ["Pareto efficiency"], so that none of the 3-win stakeholders have any interest to change his/her strategy, without losses for him/herself and for the others?

d. Could a 3-ple pole system influence the world economic and social system?

e. Could the stakeholders' behavior of being changed resulting in the social welfare process' spillover feedback? Should, a 3-ple pole system influence the world economic and social system?

f. Could the stakeholders' behavior of (locally) being changed resulting in the social "equilibrium [6] spillover feedback?

\section{Research Aim}

The paper will examine the applicability of the win-win-win papakonstantinidis conceptualization regarding to the bargaining games theory analyzing individual winning strategies, through the utilities/shares possible combinations among three "poles" in management decisions, State, Company and the Citizen.

\section{In particular,}

A. The problem is to discover labor market tends related with its competitive possibilities

B. The aim of this paper is to show the bargaining possibilities when there are three involved parties on a labor market and two of them are active decision-makers. The continuous conflict between the three main bargaining power poles i.e, State; Company; Citizen.

C. The scope is the "bargaining process" with its functions, it the labor market

D. Date Collection: Statistical date in its official form from Germany and Greece

E. Methodological tool: the win-win-win papakonstantinidis model

Understanding the nature of the bargaining problem and the behavioral dimensions of dependence and cooperation in the Labor Market channels

In order to understand the nature of the bargaining problem

Many years ago, the term "win-win" was made popular in text-books and seminars, as a business model in labor market and marketing channels [7,]. The concept of both people in an agreement "winning" was, at the time, a forward-thinking way of doing business. However, in today's rapidly changing environment of labor market channels, "win-win" simply seems to be not enough [11].

Entering a much more modern concept such as the "win-win-win" or "papakonstantinidis triple win” seems to address the missing factor in the "win-win" model. The old "win-win" model, while it worked extremely well in the past, only addresses the two parties entering an agreement, for example:

a. The Citizen and the State or

b. The Company and the State, or

c. The Company and the Citizens

However, where is the Community or the Society Potential Profit, in relation with the Labor Market? Could be the missing link?

The paper examined the applicability of an extension of the win-win-win papakonstantinidis conceptualization, as an innovative bargaining solution [12]. This study examines the bargaining possibilities when there are three involved parties on a labor market and two of them are active decision-makers. Especially, it focuses on when the social welfare development and the ethical economics could be realized better by the Community (State) participation in the socialization process and investigate the potential evolutions and research challenges on the total economy and even more in straightening human relations based on the proposed "win-win-win papakonstantinidis model] We are regarding the three poles "state", "employee of job center" and "unemployed person". We came to a possible solution of labor market

If we have the win-win-win (Papakonstantinidis) model with the following three poles, i.e State, Company and the Citizen.

In the background of digitalization and automatisation we see the following:

\subsection{Three Kinds of Business Interactions}

- In former times (and still today) business was always an interaction of human with human. (Examples: local food markets; craftsmen services)

- The second step is an interaction of humans with machines. (Examples: Self-service cash register at IKEA and other stores; online-shopping; self-driving taxis; e-law (automized juridical support for consumers))

- $\quad$ The last step is an interaction of machines with machines. (Examples: fonds which are not managed by persons but algorithms decide and buy alone on the stock market; cameras inside the fridge give information to a computer who orders fresh food by internet; a search-engine that does not just inform me, when a flight is cheap, but even buys it)

\subsection{Time-line}

The human participation on economy is getting less and less. The importance of the last two kind of business is growing hand in hand with the progress of digitalization and automatisation.

Examples are: Quantity of travelling agencies (in Germany 2002: 14.235, 2014: 9829) [13], video libaries (in Germany 2005: 4273, 2017: 601) [14], bank branches (in Germany 2004: 14.989; 2017: 9004) [15] are getting 
less or even disappear. There is a big loss of workplaces.

These are examples for business linked to consumers. Big parts of the business do not have direct linkage to the consumers. (For example, in the contracting department of insurances and electricity companies in former times were people working who are getting replaced by automated systems)

\subsection{Consequences}

a. Many workers are losing their jobs, because computers, do it cheaper (no salary, no wage labor costs), do not request for holidays, are never ill, work 24/7 don't go on strikes are (mostly) faster

b. The rising unemployment rate will lead to less consumption (of the broad mass) and accumulation of wealth at few people: big data analysts and other (IT-) specialists will have good jobs. And the wealth of the owners of the companies is exploding (see for example the big 5 of internet: Amazon, Apple, Microsoft, Google, Facebook)

A possible solution can be drawn using the 3ple win Papakonstantinidis-model:

\subsection{Interests of the Three Poles}

a. Company: Growth (perhaps "Maximize Profit" is an expression that companies deny) and contracting employees only they are cheaper/better than computers.

b. Employee: Offer work capacity on the labor market if it brings significant more money (or other benefit like reputation) than staying at home.

c. State: It should be satisfaction of the people and not the wealth of the nation (a good example is Bhutan where the Gross National Happiness is a goal in the constitution).

For achieving this, the State has to interact on the labor market. This interaction is not in the scope of this paper, but possible solutions (among others) can be financial transaction tax (for taking part of the profit from the companies) universal basic income (for supporting the unemployed people and increasing their consumption possibilities, this increases the companies benefit)

\section{Analysis}

\subsection{Situation for Unemployed People in Greece and Germany}

Greece

In October 2018 the unemployment rate was at about $18,9 \%$ [16]. The employment rate was 57,8\% [17]. After a maximum of one year the unemployment benefit which was 359,97 € [18] for a single person, ended. [19] After this, a long-term unemployment benefit [20] should be paid for a maximum of 12 further months [21]. Then the only aid was the family. Greece has a high quantity of long-term unemployed people. In Greece the situation for long-term unemployed people was fatal. Without family there is no legal possibility to survive. Karantinos [22] writes: "Greece has been facing a protracted recession since 2008." Prior to the crisis, Greece had done rather well with economic growth. Real volume GDP increased by $5.5 \%$ in 2006 and by $3.5 \%$ in 2007. The crisis struck Greece in late 2008 and since then the economy was in recession. The economic situation deteriorated further in the following years, with sharp contractions of 3.1\% (2009), 4.9\% (2010), and 7.1\% (2011) of GDP. In 2012, the overall contraction of the economy reached 6.4 percent. The effects of the global economic recession on the Greek economy reached a crisis point in early 2010, when the country was found to be on the brink of bankruptcy. Greece was granted financial aid amounting to $€ 110$ billion from the European Commission, the European Central Bank and the IMF. In exchange Greece agreed to implement a structural reform program in terms of economic, fiscal, financial and labor market policies. Based on the reforms provided for by the aid agreement, laws were passed in 2010 and in 2011 that made radical changes to employment relationships, and were aimed mainly at making the labor market more flexible and at minimizing labor costs [23]. The measures included cutting the pay of civil servants, freezing pensions, raising state revenue by increasing taxes, including VAT, and overhauling pension and employment rules. In private sector labor relations, the austerity measures envisaged various policies reformed impacting minimum salaries, redundancies, collective bargaining arbitration and severance pay cuts. New legislation provided for a reduction in pay rates for overtime work and enhanced flexibility in the management of working time [23]. The arbitration system also changed, so that both parties can now resort to arbitration if they disagree with the proposal of the mediator. Legislation on minimum wages was also adopted, that introduced sub-minima for groups at risk such as the young and long-term unemployed, and put measures in place to guarantee that current minimum wages remain fixed in nominal terms for three years.

\subsection{Law System}

New rules extended the probationary period for new jobs to one year, reduced the overall level of severance payments and ensured that the same severance payment conditions apply to blue- and white-collar workers [23]. The first financing program was followed by a second one, designed to cover the country's debt servicing needs until 2014 and put Greece on a sustainable path. The second financing program totals $€ 130$ billion, plus $€ 34.4$ billion of 
the undisbursed remainder of the first program. The second package aimed to cut the national debt to $120.5 \%$ of GDP by 2020. As part of the "prior actions" which Greece could to take in order to secure its second bailout, the government was forced to introduce deep wage, pension and healthcare cuts in early 2012. In the area of labor market policy, the Government adopted an ambitious set of labor market measures, complementing the reforms passed in 2010 and 2011. In short, the most important of the reforms entailed: a/ a new type of firm-level wage agreement, allowing employers and employees to agree on wages that are less favorable than those stipulated in sectoral agreements, b/ a reduction in minimum wages in the private sector and a modification of wage-setting procedures, including the rules on the expiration of collective agreements and the arbitration of wage disputes, c/ measures to boost part-time work and facilitate more flexible work time, and $\mathrm{d} /$ the introduction of non-subsidized sub-minimum wages for youths (Karantinos 2012) [24]

\subsection{Greece: Manpower Employment Organization (OAED)}

OAED was created in 1981, when the Social Party (PASOK) gained the elections. Manpower Employment Organization (OAED, the Greek Public Employment Service) Since at least 2000, OAED was undergoing a major organizational change, whose aim was to modernize the provision of employment services. In response to recommendations by the Commission, the new OAED is implementing, among other, the preventive approach to unemployment and the use of personalized assistance. OAED is also undergoing organizational change, including the frequent reshaping of the active labor market measures. OAED Reports are available online [23] PE 497.76018 Eures-type portal enabling the efficient matching of the demand and supply of labor. Starting also in 2014, OAED is called upon to develop an implementation plan for the so-called Youth Guarantee. According to the EU Council Recommendation of April 2013, establishing a Youth Guarantee, the scheme would ensure that every person under 25 gets a quality offer of a job, continued education, training, apprenticeship or traineeship within 4 months of leaving school or becoming unemployed. Current reform efforts focus on the "re-engineering of the OAED": this project, which was backed by the European Social Fund, envisages a plethora of actions and measures to be implemented in the course of the next two years. The reform of the OAED was clearly of critical importance for Greece, since the problem of the record high unemployment could be only effectively addressed by a modern and efficient organization. In this respect, improving the job matching capacity requires special attention. In implementing the reform, there are three issues that deserve to be classified as "items to watch". The first point relates to human resources. According to the re-engineering plan, since the start of the crisis, OAED has lost approximately $50 \%$ of its employees, in spite of the fact that unemployment has reached record levels. As in the case of SEPE, OAED must be strengthened with additional, specialized personnel, adequately trained and well remunerated. The second point relates to three groups of the population, namely young people, older workers and immigrants which are grossly underrepresented among the registered unemployed [23]. It should be noted that these three groups were among the groups most hardly hit by the recession. For reasons of fairness, OAED must make an effort to address underrepresentation, and in this frame a number of policy options are available. These include changes in unemployment compensation and networking with education establishments and NGOs for the young, the design of employment and training courses aimed exclusively at older workers and information campaigns and training of PES staff for third country nationals [22]. The final point related to the issue of collaboration with other mediating structures. The scale of the unemployment problem is such that requires a lot to be done in this direction. With a few exceptions, OAED still holds a monopoly in job brokerage, and continues to this day to be the main agency responsible for the integration of the unemployed, although there is now much more variety as regards providers of active measures. By now, it is generally accepted that private placement agencies (PRES) should coexist with the PES, and ILO Convention No. 181, 1997 revised Convention No. 96, 1949 in this direction. This Convention balances the recognition of the productive role that could be played by PRES in the delivery of specific labor market services with the need to ensure that basic rights of workers covered by this Convention are protected. The Greek government could determine whether or not PRES could operate as businesses, and, if so, under what conditions will they operate. In developing collaboration ties with other mediating structures, it is evident that a new regulatory framework, providing a common code of practice, setting rules for collaboration and exploiting synergies, is clearly needed.

\subsection{Germany}

In October 2018 the unemployment rate was at about 3,3 \% [16]. The employment rate was at 79,2\% [25]. Every employee took part on the mandatory unemployment insurance and pays 2,5\% (starting from $1^{\text {st }}$ of January 2019, before it was 3\%) [26] of his salary for being protected against unemployment. In the first year the unemployment benefit for a single person is $60 \%$ of the last net salary.[27] After one year of unemployment the unemployed person got social aid if he was needy and had no assets over a certain limit.

This basic social aid was up to $€ 424$ [28] per month plus the required money for the flat. The unemployed person could make himself be available for the labour market, 
otherwise his social aid could be reduced.

\section{Games}

The different types of games (as shown in Figure-1) are explained below.

\subsection{Cooperative and Non-Cooperative Games}

Cooperative games are the one in which players are convinced to adopt a particular strategy through negotiations and agreements between players. Let us take the example cited in prisoner's dilemma to understand the concept of cooperative games. In case, John and Mac had been able to contact each other, then they must have decided to remain silent. Therefore, their negotiation would have helped in solving out the problem.

Another example can be cited for pan masala organizations. Suppose pan masala organizations have high ad-expenditure that they want to reduce. However, they are not sure whether other organizations would follow them or not.

\subsection{Bargaining in Greece}

In Greece the unemployment rate has been the highest of all EU countries. In the same time Greece had the highest rate of black economy: 20,8\% [29] of the gross domestic product (GDP). Further 30\% [30] of the Greek population admit that they pay for undeclared work in the last 12 months.

These two numbers $(20,8 \%$ and $30 \%)$ must not be confounded, for several reasons. Some of them are:

a. There are people who could not do admit that they pay for undeclared work.

b. Some people even had not known that they pay for undeclared work.

c. The rate of the black economy could only be estimated.

d. The participation of the consumers on the black economy was not constant. Many products/services on the black market and some only few have bought by the consumers

e. The participation of the retailer on the black market was also individual. Some offered only some extra hours/products on the black market. Others were working illegal full-time.

High taxes and social security contributions did not serve as explication for the high acceptance of undeclared work. The taxes and security contributions were lower in Greece $(40,2 \%)$ than in Germany $(49,4 \%)$. [31]

In legal business we have the three bargainers:

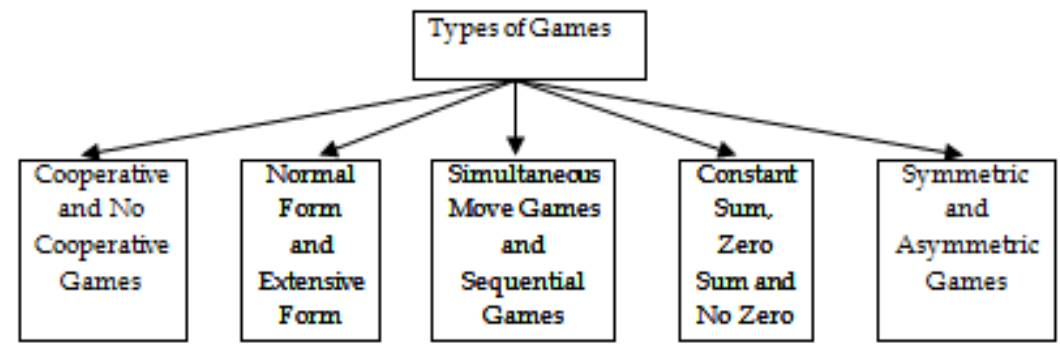

Figure 1. Types of Games

Table 1. (Un-)Employment Rates

\begin{tabular}{|c|c|c|c|c|}
\hline & $\begin{array}{c}\text { Unem- ployment rate } \\
\text { in October 2018 }\end{array}$ & Employ- ment rate in 2017 & $\begin{array}{c}\text { Unem- ployment benefit } \\
\text { per month }\end{array}$ & $\begin{array}{c}\text { Monthly social aid (after end of } \\
\text { unemployment benefit) }\end{array}$ \\
\hline Greece & 18,9 & 57,8 & $359,97 €$ (first year) & 0 (after 2 years) \\
\hline Ger- many & 3,3 & 79,2 & About $60 \%$ of net salary & $424 € /$ month (after one year) \\
\hline
\end{tabular}




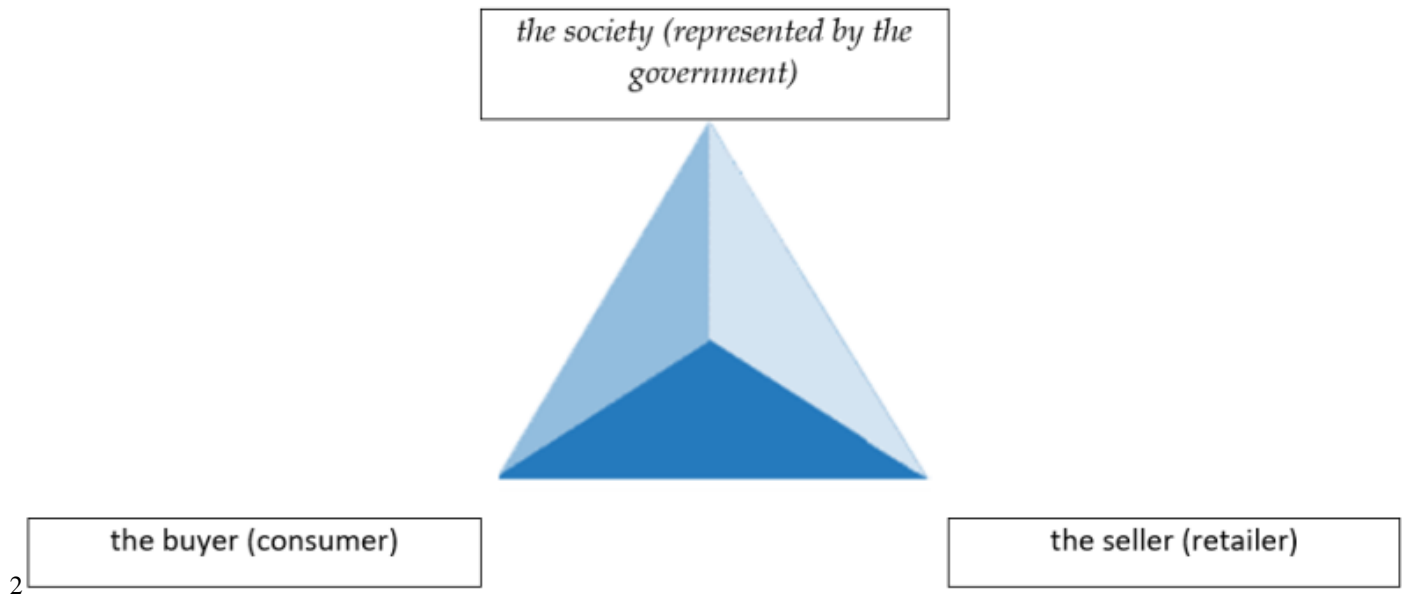

Figure 2. 3-pole-model - the three bargainers in Greek legal business

As we have the two decision-makers consumer and retailer, there are four cases to consider:

1. The consumer and the retailer want to work legal. The consumer pays 100 for a product or service and the retailer earns 60 because he must pay 40 for the state (taxes and social security).

2. The consumer wants to work legal and the retailer illegal. Often in this case, the consumer does not know that the retailer is working illegal. So, he pays 100 and the retailer earns 100 . It can happen that he is taking part on black economy without wanting.

3. The retailer is an honest person, but the consumer is asking for illegal work: No job will be done.

4. Both decide to cheat the state and divide the money that should be paid for taxes and social security. The consumer pays 75 and the retailer earns 75 . The state earns nothing. This case is not usual in small business, like supermarkets and restaurants, but it is common for bigger jobs like car repairing.

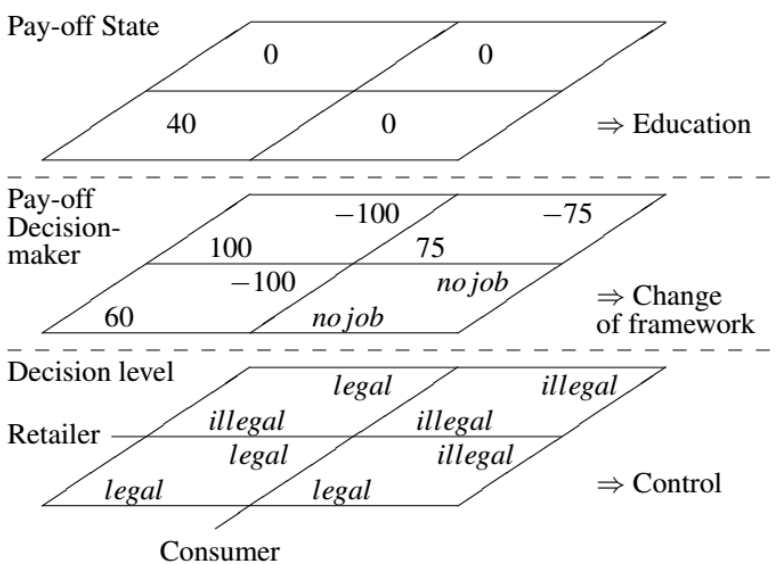

Figure 3. 3-pole model with payoffs - Greek economy (own visualisation)

There are two possible main reasons for the people working in undeclared jobs, because they cannot find legal jobs, or their intention is to avoid taxes. Finding an answer on this question does not change the behavior of the people. For changing their behavior there exist three possibilities, which we can see in the following three-level model which highlights the payoff of the three involved parties depending on the decision of the consumer and retailer.

The State has, according to the Expanded Game Theory [32] there are three possibilities to influence on the decision-makers: Control them, change the framework and educate them

\section{A. Control}

In 2013 the Greek government launched the law that restaurants only must be paid if receipts are handed out [33]. This reduces frauds, but does not completely avoid them, because the consumer has no benefit in asking for a receipt.

In the future with growing popularity of electronic cash, it will be even easier to control the way of the money and avoid frauds.

\section{B. Change of Framework}

In 2017 the Greek tax lottery was launched.[34] This lottery is a big success in Brazil since 2007.[35] It gives a strong motivation for the consumer to ask for legal service/products. "Tax authority's one million euros lottery boosts card use in Greece) [36]

This is a change of framework because the rules of the "game" changed. Before, the motivation for the consumer to force the retailer to work legal was 0 . Now it is a lottery coupon.

Notes:

a. As the black economy in Greece is often (but not always) related to foreign tourists who cannot take profit of the lottery, an expansion of the lottery would be a help for increasing its benefit.

b. The big national companies like banks and petrol companies have much more "difficulties" in 
participating on the black economy than the small retailers and restaurant owners. For them a consumer who asks for legal service/products does not change anything, because all service and products are legal.

\section{Education}

In 2018-2019 a triple basic reform, were voted as laws from the Greek Parliament:

a. Strengthen the role of the high school in the national educational system

b. Change the way of entrance from the high school to the public universities

c. Merging Universities and Technological Educational Institutes, so to reduce their number in terms of their scientific fields. Currently, there is a conflict between SYRIZA political party (Government) and the "New Democracy" Party (Official Opposition) on the Private Universities (Article 16 of the Constitutional Law) and the "students' loans".

These educational long-term investments are helping to increase the potential of the Greek workers on the global labor market and if the right lessons are taught, they sensitize the population on better differentiate between ethical and unethical behavior.

\subsection{Results for Greece}

In 2013 the unemployment rate in Greece was 27.5\% and now is at about 19\%.[37] This is a reduction of almost $50 \%$ of unemployment. The black economy was reduced by the above-mentioned methods (and others). Perhaps not all the published growth of economy of 1,35\% [38] in 2017 is a real growth but a shift from the black economy to official economy. In 2018 the estimated growth of about 2,02\% [39] is also partly based on this shift. Nevertheless, such a shift to "white" economy is right against the society and its fair members.

We see, that the Papakonstantinidis 3ple win-win-win-model creates added value for all three poles:

a. The government earns more taxes and pays less for social aid.

b. The consumers have the benefit of the lottery: They also can have good conscience on participating on something good.

c. They can have the same good conscience like the consumers. The retailers on long term will have to pay less for social security and taxes, because if more retailers pay, the rates can be reduced. For example, in Germany the unemployment security contribution was reduced from $3 \%$ to $2,5 \%$ on $1^{\text {st }}$ of January 2019 , due the low unemployment rate.

\subsection{Bargaining in Germany}

In Germany the situation is completely different from Greece. There the economy is almost under full employment. It is hard to reduce any more the unemployment rate of currently 3,3\%. The economy demands for professionals and the government is planning a Fachkräfteeinwanderungsgesetz [40] (immigration law for professionals). Therefore, in Germany a reduction of black economy cannot increase significant the legal market.

In Germany another bargaining is interesting to highlight:

The unemployed people are administrated by the "Bundesagentur für Arbeit "(BfA) (employment agency), which has about 95.000 employees [41].

In 2014 about 1.7 million unemployed people found their (new) job without the employment agency. The employees of the employment agency found regular 271.000 jobs for unemployed people in Germany [42]. This is a ratio of less than 3 jobs per employee of the employment agency.

The same source [42] informs that after one year only $57 \%$ of the people who found their job with the aid of the BfA are working and covered by social insurance ("sozialversicherungspflichtig"). This reveals that $43 \%$ of the work of the BfA had no long-term benefit and reduces the rate to 1.6 long-term jobs arranged per employee of the agency. This ratio seems to be very low. This has several reasons:

a. The employment agency is not only responsible for the unemployed people. It has much more jobs. For example, it administrates and pays the child benefit (“Kindergeld”).

b. Often the job researchers of the employment agency only get in touch with the unemployed people, who are not able or willing to find a job on their own.

There is almost full employment, with about 820.000 [43] long-term unemployed people and 95.000 workers at the BfA. In the same time there about 795.000 [44] vacant jobs in Germany registered at the BfA. Of course, not all these long-term unemployed people have the necessary qualification and geographic flexibility to these jobs, but it is obvious, that not all of them are interested and/or able to work in a regular job. This is highlighted by the fact, that $43 \%$ of the job-arrangements of the BfA are cancelled within less than one year.

\subsection{Results for Germany}

We have the following three bargainers: 


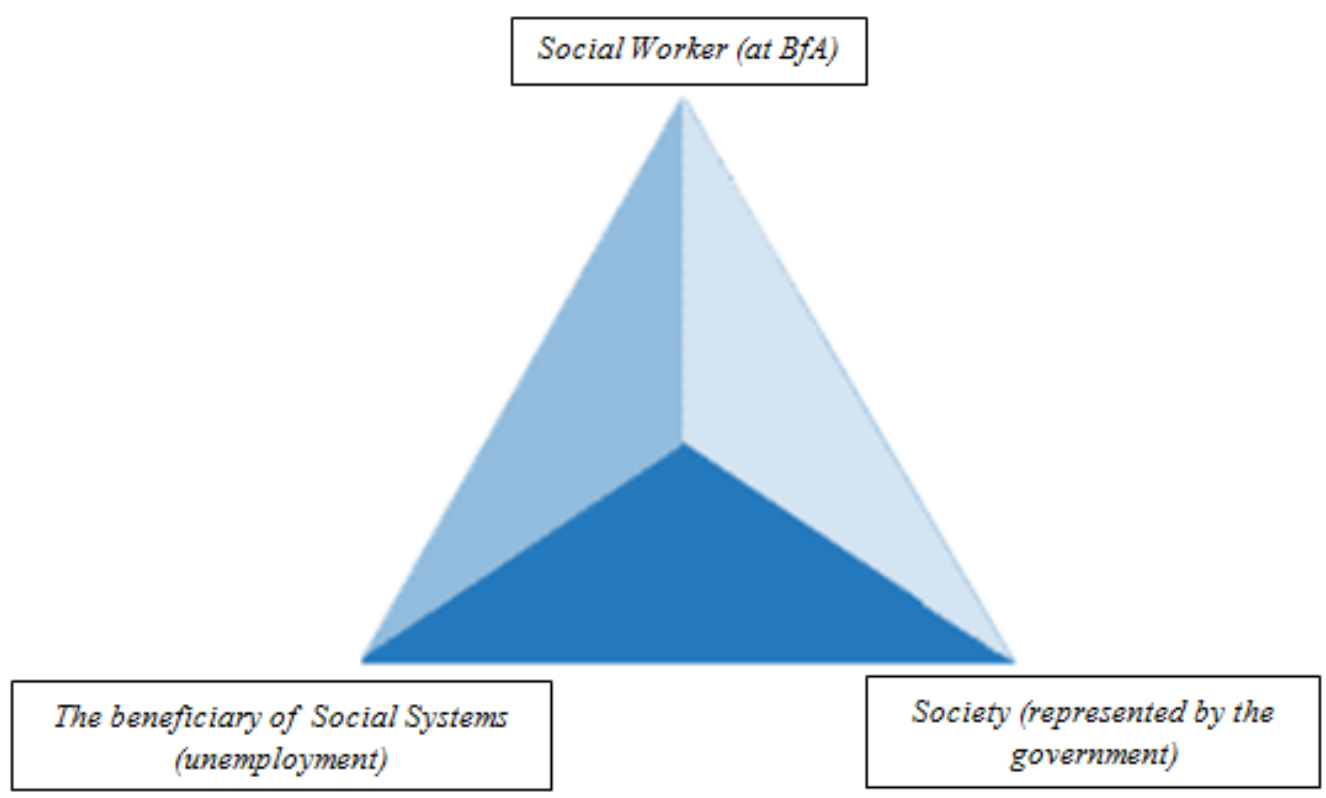

Figure 4. 3-pole model of German job-agency

There are again four possibilities:

1. The unemployed person has been really searching for a job and the worker at the BfA is searching, too. Both have hope for having success in searching and if they have success, there will be profit for both and even for the state (taxes of the new employee, and less costs for the social system). This can lead to a possible profit for the state, because if they are successful, the expenditures for social aid will be reduced and the taxes will be raised.

2. Both know about the little probability of finding a job at the BfA. Both decide that passive management is the most convenient situation for them. This means, that the required papers for getting the social aid are fulfilled correctly and both spend their time with goals which promise more benefit that searching a job for this unemployed person. This resignation constellation does not bring benefit for the society, but it is still cheaper for the government than the last two options.

3. The worker at the BfA is motivated to help his customer and invests time in searching a job. But the unemployed does not expect much help from the BfA. He knows that the worker in the BfA will not be a big help for finding a job that fits to him. In $85 \%$ of the cases he will find a job without the BfA and the jobs offered by the BfA are mostly not so good and lead to a dropout rate of $43 \%$. Therefore, he prefers passive management of the BfA. Both are stressed, because of non-congruent expectations. This is expensive for the government who pays the worker at the BfA.

4. The unemployed person is expecting help for his job-search, but the worker at the BfA knows that their probability to find a job without him is more than 6 times higher, than with him. Therefore (and perhaps of the high workload) he only is doing passive management of his customer. We have the same stress-situation as before which is again expensive for the government.

In this visualization we can see, that the best situation is, when both decision-makers are searching and having hope. The government shall support them on this way by educating them, controlling them and motivating them with an adequate pay-off. Currently the BfA use these three keys to influence on the two decision-makers.

If case 1 does not lead to a job in an appropriate time, at least one of the two bargainers will lose hope, and this will lead to one of the other cases. In case 2 and 3, probably there is a high stress level, because of the (unspoken) different expectations. In the last case both parties have arranged with the situation and know that administrating the situation is the cause of the smallest conflicts.

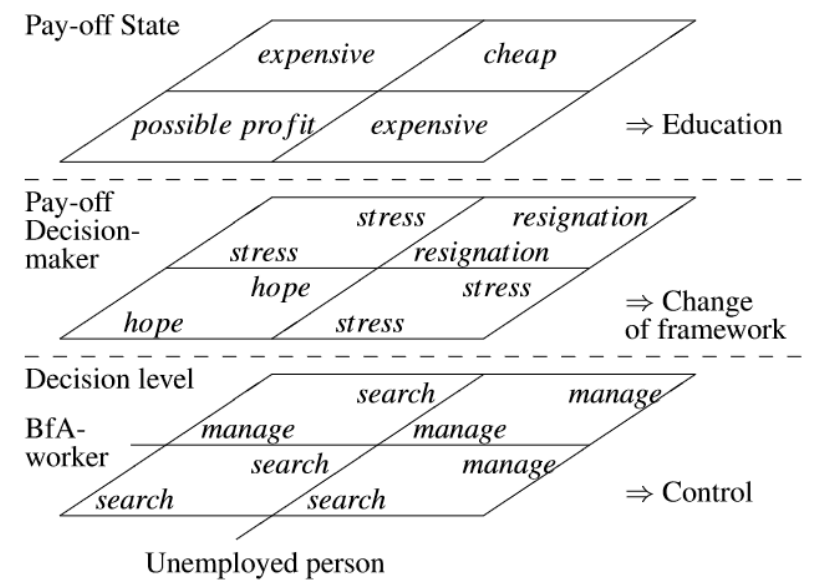

Figure 5. 3-pole model of German job agency with payoffs (own visualisation) 
After a certain time at least, one will lose hope. After reaching this point of no return, the government has only costs, if it keeps forcing the two decision-makers in searching for a job, because senseless trainings are done and the worker at the BfA cannot care on more promising candidates. This means that the government shall not force the employees of the BfA to work longer than a certain time on one case and that (after a time) there shall not be a punishment for the unemployed person if he rejects a job. This leads to the "basic income" which is an unconditional income for every citizen. This idea is often discussed, and its economic and social benefits are now highlighted with the 3ple win-win-win model. In this case there is no winner, but the loss can be minimized.

\section{Conclusions}

We have two completely different situations for bargaining, but in both cases clever bargaining leads to a more sustainable economy because expensive resources are not misdirected to the black market or inefficient work.

The 3d-visualizations (Figures 2 and 4) show, how a certain profit can guarantee for all three parties: For the two decision-makers and the society as well. It also shows the three handles of the society to influence on the decision-makers: control, change framework and education.

The two chosen examples help to understand the broad usability of the win-win-win Papakonstantinidis model. It unifies the advantages of the stakeholder model and the classical game-theory because, like the stakeholder model it shows whom to consider, but it eliminates the big weakness of the stakeholder model, that does not allow forecasts. With the new model it is possible to predict the behavior of the bargainers like in the classical game theory.

Table 2. Black economy

\begin{tabular}{|c|c|c|c|}
\hline & $\begin{array}{c}\text { Paid for } \\
\text { undeclared } \\
\text { work [30] }\end{array}$ & $\begin{array}{c}\text { Black } \\
\text { economy in \% } \\
\text { of GDP [45] }\end{array}$ & $\begin{array}{c}\text { Taxes and social } \\
\text { security } \\
\text { contribution [31] }\end{array}$ \\
\hline Greece & $30 \%$ & $20,8 \%$ & $40,2 \%$ \\
\hline Germany & $7 \%$ & $9,5 \%$ & $49,4 \%$ \\
\hline & Consumer & Worker & State \\
\hline
\end{tabular}

The situation in the in the regarded countries is completely different:

In Germany there is a long-term social aid with (weak) control and (little) sanctions if the unemployed people are not willing to work. In the win-win-win-papakonstantinidis model the three bargainers are winning.

This will be the next step to be illustrated.

German system:

Possible solutions (among others) can be:

a. Taking away (from the employment agency) the work that has nothing to do with unemployment transfer it to organisations which are specialised b. Taking away the job search transfer it to private companies who do it better

c. Improve the efficiency of administrating unemployed people for

d. Automatization of processes

In Short:

A. The beneficiary of the social system can cooperate with the system and the social worker or he can refuse cooperation.

B. The social worker faces two kind of unemployed people:

a) The one who is cooperating and really searching for a job

b) The one who is refusing cooperation and only wants the money from the system

Cooperation with type a) is a Papakonstantinidis win-win-win situation. A cooperation with type b) can be b1) pushing and pulling or b2) simply giving him (a reduced) aid

C. The society has the three possible levers for influencing on the two decision makers:

- Education

- Adaption of the framework

- Control

Future analysis and application of the 3ple win-win-win-papakonstantinidis model can be done in other parts of the welfare system (health care, crime evasion) and the effects of the unemployment benefits on the other parts of welfare system can be regarded [46, 47, $48,49]$

\section{REFERENCES}

[1] Wilkinson, 1991 "The Community in Rural America" Publisher ABC-CLIO Praeger Publishers Inc 28 Feb 1991 Westport, United States.

[2] Rammonet Ignacio ( 2006) Silent Thought” LE MONTE DIPLOMATIQUE, May, 2006

[3] Manuel, Castells (1996). The information age: economy, society and culture. Oxford: Blackwell.

[4] Papakonstantinidis LA (2013) "Involving Communities In Rural Tourism: A "Win-Win-Win Papakonstantinidis Model” Methodological Approach Case Studies: Women Rural Tourism Cooperatives: A) Gargaliani, Peloponnesus Area (South-West Gr) B) Wert (Women Entrepreneurs In Rural Tourism) 10th - 11th September 2013 Kotka, Finland Merja Lohdesm $\delta$ ki Ja Anne Matilainen

[5] Papakonstantinidis LA (2019) "The win-win-win papakonstantinidis model: towards a new equilibrium?” LAMBERT Academic Publishing, January 2019

[6] Papakonstantinidis L.A (2005) "Uj Iranyok a Regionalis Politikaban a Terulet-ter Mechatarozasa Haruomszintu 
Alkufolymatkent- A "Nuer-Nyer-Nyer Modell" Esettanulmany: A LEADER EU Kezdemenyezes Alkalmazasa Gorogorszagban (New trends in Regional Policy: Territory-Space Definition by a 3-level Bargaining Approach- The win-win-win model. Case study The LEADER EU Initiative Application in Greece- "Ter es Tarsadalom” (Journal of Space and Society) - Hungarian Academy of Sciences/Regional Studies Dpt - XIX enf 2005 iss p.p 95-109 (translated into Hungarian)

[7] David M. Bell (2012) "Method and Post-method: Are They Really So Incompatible?” TESOL Quarterly Volume 37, Issue 2 First published: 04 January 2012 https://doi.org/10.2307/3588507

[8] Evert Gummesson (1999) "Total Relationship Marketing: Experimenting With a Synthesis of Research Frontiers"Australasian Marketing Journal (AMJ) Volume 7, Issue 1, 1999, Pages 72-85

[9] Spais-Papakonstantinidis LA -Papakonstantinidis Stavros (2009)An innovative bargaining solution analysis for vertical cooperative promotion management decisions Innovative Marketing, Volume 5, Issue 3, 2009

[10] Statista: Anzahl der Reisebüros in Deutschland von 2002 bis 2017, acessed on 09.03.2019. Available at: https:/de.statista.com/statistik/daten/studie/252715/umfrag e/anzahl-der-deutschen-reisebueros/

[11] Statista: Stirb langsam - Immer weniger Videotheken in Deutschland, acessed on 09.03.2019. Available on: https://de.statista.com/infografik/10812/anzahl-der-videoth eken-in-deutschland/

[12] Statista: Das Sterben der Bankfilialen, acessed on 09.03.2019, Available on:https://de.statista.com/infografik/ 14350/anzahl-der-kreditinstitute-und-bankfilialen-in-deuts chland/

[13] Eurostat: Unemployment statistics, accessed on 09.03.2019. at:https://ec.europa.eu/eurostat/statistics-explained/index.p hp?title=Unemployment_statistics

[14] Eurostat: Unemployment rate by sex, age group 20-64, accessed on 09.03.2019. Available at:https://ec.europa.eu/e urostat $/$ tgm/table.do?tab=table\&init=1\&language=en\&pco de=t2020_10\&plugin=1

[15] Living in Greece: Unemployment benefits in Greece, accessed on 09.03.2019. Available at:http://livingingreece. gr/2007/03/17/who-can-collect-unemployment-payments-i n-greece/

[16] A-kasser: Unemployment benefits in Greece, accessed on 09.03.2019. Available at:https://www.a-kasser.dk/unemplo yment-insurance-in-europe/greece/

[17] Handelsblatt: Hartz IV auf Griechisch, accessed on 09.03.2019. Availableat:https://www.handelsblatt.com/pol itik/international/grundsicherung-in-europa-und-den-usa-h artz-iv-auf-griechisch/10968098-all.html (in German)

[18] ELSTAT (the Greek Statistics).

[19] Dimitris Karantinos(2014) “An evaluation of the social and employment aspects and challenges in Greece” Directorate General for internal policies economic governance support unit (egov) - national centre for social research (ekke)

[20] ELSTAT: Greece Unemployment Sept 2018https://www.fo cus-economics.com/countries/greece/news/unemployment/ unemployment-rate-drops-again-in-september

[21] EEO- Karantinos: Ad hoc paper: "The impact of the crisis on the Greek labour market” ad hoc request, October 2012 Prepared by Dimitris Karantinos, SYSDEM Correspondent for Greece. 1

[22] Eurostat: Unemployment statistics, accessed on 09.03.2019. Available at:https://ec.europa.eu/eurostat/tgm/table.do?tab $=$ table\&init $=1$ \&language $=$ en \&pcode $=$ t2020_10\&plugin $=1$

[23] Sozialversicherung kompetent: Beitragssatz Arbeitslosenve rsicherung 2019, acessed on 09.03.2019. Available at: https://sozialversicherung-kompetent.de/sozialversicherun g/zahlen-werte/867-beitragssatz-arbeitslosenversicherung2019.html (in German)

[24] Bundesagentur für Arbeit: Anspruch Höhe, Dauer Arbeitslosengeld, acessed on 09.03.2019. Available at: https://www.arbeitsagentur.de/arbeitslos-arbeit-finden/ansp ruch-hoehe-dauer-arbeitslosengeld (in German)

[25] HartzIV.org: Hartz IV Erhöhung kommt: Mehr Geld ab 2019, acessed on 09.03.2019. Available at:https://www.hartziv.org/news/20180912-hartz-iv-erhoeh ung-kommt-mehr-geld-ab-2019.html (in German)

[26] Statista: Prognose um Umfang der Schattenwirtschaft in ausgewählten Ländern der OECD im Jahr 2019 (in Prozent des offiziellen BIP, acessed on 09.09.2019. Available at:https://de.statista.com/statistik/daten/studie/163720/umfr age/schattenwirtschaft-in-der-oecd-2010/ (in German)

[27] European Commission: Undeclared Work in the European Union, page 18, accessed on 09.03.2019. Available at: http://ec.europa.eu/commfrontoffice/publicopinion/archive s/ebs/ebs_402_en.pdf

[28] Spiegel Online. Deutschland ist Zahl-Vizemeister, accessed on 09.03.2019. Available at:http://www.spiegel.de/wirtsch aft/soziales/steuern-deutschland-ist-vizemeister-bei-der-ab gabenlast-a-1142772.html (in German)

[29] Thomas Kronberger: Unethical cooperation and its consequences for stakeholders, Insights from Game Theory in "Management in Theory and Practice", Brno

[30] Greek Reporter: Tax Evasion Plan: No Reciept, No Pay, accessed on 09.03.2019. Available at:https://greece.greekr eporter.com/2012/10/26/tax-evasion-plan-no-receipt-no-pa $\mathrm{y} /$

[31] Naftemporiki: Tax receipt lottery finally debuts in Greece, accessed on 09.03.2019. Available at:https://www.naftemp oriki.gr/story/1300421/tax-receipt-lottery-finally-debuts-in -greece-on-thur

[32] Agora: Nota Paulista tem 100 mil queixas. Acessed on 09.03.2019. Available at:http://www.agora.uol.com.br/gra na/ult10105u791442.shtml (in Portuguese)

[33] Tornos News: Tax authority's one million euros lottery boosts card use in Greece. Acessed on 09.03.2019. Available at: https://www.tornosnews.gr/en/greek-news/ec onomy/28581-tax-authority-s-one-million-euros-lottery-bo osts-card-use-in-greece.html

[34] Statista: Griechenland: Arbeitslosenquote von 2008 bis 2018, acessed on 09.03.2019. Available at:https://de.statista.com/ statistik/daten/studie/17312/umfrage/arbeitslosenquote-in- 
griechenland/

[35] Statista: Griechenland: Wachstum des realen Bruttoinlandsprodukts (BIP) von 2008 bis 2018 (gegenüber dem Vorjahr), acessed on 09.03.2019. Available at:https://de.statista.com/statistik/daten/studie/14538/umfra ge/wachstum-des-bruttoinlandsprodukts-in-griechenland/

[36] Statista: Griechenland: Wachstum des realen Bruttoinlandsprodukts (BIP) von 2008 bis 2018 (gegenüber dem Vorjahr), acessed on 09.03.2019. Available at:https://de.statista.com/statistik/daten/studie/14538/umfra ge/wachstum-des-bruttoinlandsprodukts-in-griechenland/

[37] Bundesministerium des Inner, für Bau und Heimar: Fachkräftezuwanderungsgestz, acessed on 09.03.2019. Available at: https://www.bmi.bund.de/SharedDocs/gesetz gebungsverfahren/DE/fachkraefteeinwanderung.html

[38] Bundesagentur für Arbeit: Geschäftsbericht 2017, acessed on 09.03.2019. Available at:https://con.arbeitsagentur.de/p $\mathrm{rod} / \mathrm{apok} / \mathrm{ct} / \mathrm{dam} /$ download/documents/Geschaeftsbericht-2 017_ba017197.pdf

[39] Antwort der Bundesregierung auf kleine Anfrage: Vermittlung der Arbeit, acessed on 09.03.2019. Available at: http://dip21.bundestag.de/dip21/btd/18/040/1804073.pd $\mathrm{f}$ (in German)

[40] Statista: Anzahl der Langzeitarbeitslosen in Deutschland im Jahresdurchschnitt von 2007 bis 2019, acessed on 09.03.2019. Available at: https://de.statista.com/statistik/da ten/studie/666199/umfrage/anzahl-der-langzeitarbeitslosen -in-deutschland/

[41] Statista: Bestand a gemeldeten offenen Arbeitsstellen in Deutschland im Jahresdurchschnitt von 2007 bis 2019, acessed on 09.03.2019. Available at:https://de.statista.com/ statistik/daten/studie/2903/umfrage/jahresdurchschnittswer te-des-bestands-an-offenen-arbeitsstellen/

[42] Statista: Prognose zum Umfang der Schattenwirtschaft in ausgewählten Ländern der OECD im Jahr 2019 (in Prozent des offiziellen BIP), acessed on 09.03.2019. Available at:https://de.statista.com/statistik/daten/studie/163720/umfr age/schattenwirtschaft-in-der-oecd-2010/

[43] US National Library of Medicine, National Institue of Health, Health Effects of Unemployment Benefit Program Generosity, accessed on 09.03.2019. Available at: https://www.ncbi.nlm.nih.gov/pmc/articles/PMC4318319/

[44] Nash J. (1951) Non-Cooperative Games. The Annals of Mathematics, Second Series, Volume 54, Issue 2 (Sep., 1951), 286-295. Crossref

[45] Arrow, Kenneth J. (1951b). Social choice and individual values (1st ed.). New Haven, New York / London: J. Wiley / Chapman \& Hall.

[46] Papakonstantinidis Leonidas A. "CSR: An application of the "win-win-win papakonstantinidis model" (BOOK) LAMBERT Publishing (2018)

[47] Brno, 2017, work on Expanded Game Theory:Thomas Kronberger: Unethical cooperation and its consequences for stakeholders, Insights from Game Theory in "Management in Theory and Practice" 